\title{
Evidence of visual hemineglect in an archeological specimen?
}

Sir,

Visual hemineglect is a well-known phenomenon commonly associated with right hemispheric brain injury-usually an ischemic stroke. Although more common with a right hemispheric pathology, hemineglect has been occasionally observed with left hemispheric strokes as well. ${ }^{[1,2]}$ Within the right hemisphere, a number of separate lesion sites can produce neglect behavior. Samuelsson and colleagues ${ }^{[3]}$ found a close correlation between visuospatial neglect and lesions of the middle 
temporal gyrus and temporoparietal paraventricular white matter. More recently, Karnath and colleagues ${ }^{[4]}$ found that isolated left hemispatial neglect correlated best with lesions on the right superior temporal gyrus.

The phenomenon of visual hemineglect (all left hemineglects) has been demonstrated in the art works of a number of artists (painters and sculptors) from Europe,$^{[5-7]}$ the most notable amongst them being the famous German painter Lovis Corinth (1858-1926). ${ }^{[8]}$ All these artists developed left visual hemineglect following right hemispheric ischemic strokes. There is no report of right visual hemineglect evidenced in the work of an artisan yet.

In March 2009, the Directorate of Archaeology and Museums of the Government of West Bengal, India, conducted archaeological excavations in the northern Bengal district of Murshidabad and excavated several metal and terracota objects dating back to the time of the Pala dynasty which ruled Bengal around the sixth century. Of the various objects excavated, was a stucco (a mixture of sand, brick dust and stone dust) head detached from its body (a statuette). The excavation findings were reported in a national daily (The Telegraph 20 March 2009). By kind courtesy of the Directorate of Archaeology and Museums, the author had an opportunity to examine this detached stucco head [Figure 1] in detail.

The head was brick red in color and measured about $6 \mathrm{~cm}$ in length. Close examination revealed that the left half of the specimen (viewer's left) was beautifully curved, specially the left eye and carvings on the head (possibly curly hair) and it appeared that the stucco head had belonged to a sculpture of a female. The lower portion of the right half of the face (viewer's right) was broken. But although the upper portion remained intact, it showed rather poor artistic carvings. The eye was ill formed and the carvings on the head (so well done on the left side) were virtually absent. The back of the head was broken.

The author argues that the ill-curved right portion of this stucco head most likely represents the work of an artisan who suffered from right visuospatial hemineglect. It is surmised that this resulted from a fairly localized lesion in the left parietotemporal region (cortex or deep white matter) of the artisan which spared the motor cortex as the motor skill of the artisan is quite obvious noting the exquisite carvings on the left portion of the specimen. It is argued that the artisan probably had an ischemic pathology from occlusion of the posterior branch of the left middle cerebral artery. It is highly unlikely that the specimen was the work of an artisan with right hemianopia as in that case the right half would not have been sculptured at all. Furthermore, although it might be possible that the age of the specimen and the very

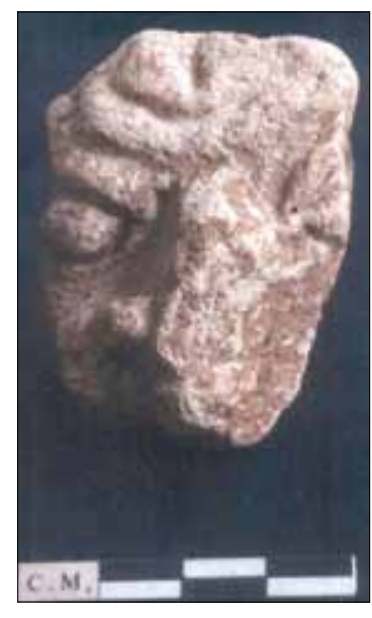

Figure 1: The stucco head

process of excavation played a role, the sculpturing difference between the left half and the intact portion of the right half (viewer's) was quite striking for the author to hypothesize on the phenomenon of right hemineglect in the artisan being portrayed in the stucco head specimen.

Mistakes made by the ancient artisans are evident in some archaeological artifacts. Notable example is the major rock edict of Ashoka the great (304 BC-232 BC) at Jonnagiri in Kurnool district, India. In this, one of the edicts out of 14 was inscribed on the rock on a hillock. The artisan inscribed the words from right to left as is the practice in the case of Kharosthi incriptions of Ashoka. But Jonnagiri was in Brahmi script and should have been inscribed from left to right and the mistake was attributed to the fact that the artisan was illiterate and probably was used to writing Kharosthi inscriptions on stones.

In the present report, however, the ill-sculptured right half of the stucco head most likely resulted from a neurological deficit in the artisan. Right visuospatial heminglect is uncommon but can certainly occur. If the hypothesis proposed here is correct, the present specimen (the stucco head) may be considered as the earliest example of the phenomenon of visuospatial hemineglect in an artist.

Ambar Chakravarty Department of Neurology, Vivekananda Institute of Medical Sciences, Kolkata, India. E-mail: saschakra@yahoo.com

PMID: 19934577

DOI: $10.4103 / 0028-3886.57794$

\section{References}

1. Krishner HS. Disorders of the right hemisphere. In: Krishner HS, editor. Behavioral Neurology. Practical science of mind and brain. $2^{\text {nd }} \mathrm{ed}$. 
Boston: Butterworth-Heinemann; 2007. p. 159-78.

2. McGlone J, Losier BJ, Black SE. Are there sex differences in hemispatial visual neglect after unilateral stroke? Neuropsychiatry Neuropsychol Behav Neurol 1997;10:125-34.

3. Samuelsson H, Jenson C, Ekholm S, Naver H, Blomstrand C. Anatomical and neurological correlates of acute and chronic visuospatial neglect following right hemisphere stroke. Cortex 1997;33:271-85.

4. Karnath Ho, Ferber S, Himmelbach M. Spatial awareness is a function of the temporal not the posterior parietal lobe. Nature 2001;411:950-3.

5. Chatterjee A. The neuropsychology of visual artistic production. Neuropsychologia 2004;42:1568-83.

6. Bazner H, Hennerici MG. Painting after right hemispheric stroke-case studies of professional artists. In: Bogousdavsky J, Hennerici MG, editors. Neurological disorders in famous artists-Part 2. Basel: Karger; 2007. p. 1-13.

7. Dieguez S, Assal G, Bogousslavsky J. Visconti and Fellini: From left social neorealism to right hemispheric stroke. In: Bogousslavsky J, Hennerici MG, editors. Neurological disorders in famous artists - Part 2. Basel: Karger; 2007. p. 44-74.

8. Bazner H, Hennerici MG. Lovis Cornith: Integrating hemineglect and spatial distortions. In: Bogousslavasky J, Hennerici MG, editors. Neurological disorders in famous artists - Part 2. Basel: Karger; 2007. p. $30-43$.

Accepted on 06-08-2009 